\title{
Antibacterial Activity of Papaya (Carica papaya) Leaf and Seed Extracts Against Some Selected Gram-Positive and Gram- Negative Bacteria
}

\author{
Eshetu Dagne, Beyene Dobo*, Zufan Bedewi
}

\section{Eshetu Dagne, Beyene Dobo*,} Zufan Bedewi

College of Natural and Computational Science, Department of Biology, Hawassa University, ETHIOPIA.

\section{Correspondence}

\section{Beyene Dobo}

College of Natural and Computational Science, Department of Biology, Hawassa University, ETHIOPIA

E-mail: csilva@unitru.edu.pe

History

- Submission Date: 12-05-2021;

- Review completed: 11-09-2021;

- Accepted Date: 03-11-2021.

DOI : 10.5530/pj.2021.13.223

Article Available online http://www.phcogj.com/v13/i6

\section{Copyright}

(C) 2021 Phcogj.Com. This is an openaccess article distributed under the terms of the Creative Commons Attribution 4.0 International license.

\begin{abstract}
Background: Medicinal plants are well-known natural sources of remedies, used in the treatment of innumerable diseases since antiquity. Wide range of medicinal plant extracts are used to treat several infections as they have potential antimicrobial activity. Objectives: This study was aimed to investigate antibacterial activity of Carica papaya leaf and seed with different solvents against Gram negative and Gram positive bacteria. The leaves and seeds of Carica papaya were dried, powdered and extracted with $80 \%$ of Acetone, Ethanol, Methanol and water. Disc diffusion method was used for the antibacterial assay and measuring the zone of inhibition, and the MIC was determined by broth macro dilution method. Results: The highest percent yield of crude extract $72.5 \%$ was obtained from Carica papaya leaf with Methanol, Ethanol and Acetone as solvents while, the lowest yield $24 \%$ was obtained from Carica papaya seed with Acetone extract. All Crude extracts from the different plant parts showed antibacterial activity. Accordingly, Carica papaya Seed with Ethanol extract exhibited the highest antibacterial activity $14.3 \pm 1.2$ $(\mathrm{mm})$ against $P$. aeruginosa which was lower than standard antibiotic disc Ciprofloxacin with inhibition zone of $25.9 \pm 0.00(\mathrm{~mm})$, while the lowest inhibition of $3.8 \pm 0.5(\mathrm{~mm})$ was recorded from Carica papaya leaf with Ethanol crude extract against E. coli. The MIC of $12.5 \mathrm{mg} / \mathrm{ml}$ was observed from Ethanol crude extract of Carica papaya seed on P. aeruginosa. Crude seed extract of Ethanol showed the highest antibacterial activity. The results of the antibacterial assay of the crude extract of Carica papaya (leaf and seed) with four different solvents showed zone of inhibition against all tested bacteria. However, among the plant parts of Carica papaya included in the current study, the seed of Carica papaya were found to be the best source of antibacterial agents. Conclusion: In this study, limited (only leaf and seed parts) of Carica papaya was tested for its antimicrobial activity. So, the same work should be carried out on different parts of Carica papaya plant like; bark, root, flower and fruits on antibacterial activities so, as to have a clear picture of the spectrum of antibacterial activity of the plant.
\end{abstract}

Key words: Antibacterial activity, Bacterial pathogens, Carica papaya, Medicinal, MIC.

\section{INTRODUCTION}

\section{Background of the study}

Medicinal plants are well-known natural sources of remedies, used in the treatment of innumerable diseases since antiquity. Many plants from various Brazilian biomes, such as the Cerrado (savannahlike), the Atlantic (uplands) and the Amazon (lowlands) rain-forests, have been used as natural medicines by the local population in the treatment of tropical diseases, including leishmaniasis, malaria, schistosomiasis, fungal and bacterial infections.

Medicinal plants are abundant source of antimicrobial molecules. Wide range of medicinal plant extracts are used to treat several infections as they have potential antimicrobial activity. Some of these bioactive molecules are screened and traded in market as raw material for many herbal industries. ${ }^{2}$ Plants are rich in a wide variety of secondary metabolites, such as tannins, terpenoids, alkaloids, and flavonoids, which have been found in vitro to have antimicrobial properties. Experts turned their concentration back towards obtaining advantages from medicinal plants after observing more side effects of synthetic drugs compared to their benefits. ${ }^{3}$
It is estimated that about 35,000 to 70,000 plant species are used as medicinal plants out of 422127 reported worldwide plant species. ${ }^{4}$ In Pakistan $80 \%$ of the population belonging to the rural areas depends on the traditional medicines. ${ }^{5}$ In Nepal, the juice of Artemisia indica is used to treat stomachic, diarrhea, dysentery, abdominal pains and relieving burning sensation in conjunctives. ${ }^{6}$

Currently, studies on herbal medicines appear under different names, such as plant medicines, phytomedicines, and natural products and under pharmacognosy usually referring to products processed from living organisms: plants, animals, insects, microorganisms and marine organisms. A tropine, morphine, quinine, ephedrine, warfarin, salicin, digoxin, vincristine, taxol, and hyosine are some examples of extracts from traditional plants currently used in modern medicines. Findings from ethnobotanical and ethno medicinal studies have shown correlation between medicinal use and laboratory results. Natural sources are usually the starting points for most pharmacological agents.

The Ethiopian flora is estimated to contain between 6,500 and 7,000 species of higher plants of which about $12 \%$ are endemic. Ethiopia is also a home for many languages, cultures and beliefs that have in turn contributed to the high diversity of traditional 
knowledge and practice of the people, which among others include the use of medicinal plants. More than $95 \%$ of traditional preparations in the country are of plant origin. ${ }^{8}$

Besides bacteria, infectious diarrhoea can be caused by viruses and parasites. The prevalence of each pathogen varies with geographical region and population factors. Bacteria, for instance, are responsible for $10-55 \%$ of diarrhoeal episodes, with the highest number of episodes occurring in the developing world. ${ }^{10}$

Currently there are different types emerging diseases and other drug resistance diseases. It is very difficult to cure human and animal with the currently known drugs, therefore there is a need of other alternative drugs. Antibacterial effects against certain resistant infectious pathogens are profound and effective if combinations of different plant extracts are used. ${ }^{11}$ Various studies have established that herbal medicines can be developed as safe, effective and less costly alternatives to the current medicines to the treat certain bacterial infections. ${ }^{12}$

Therefore, the objective of the present study is to investigate the antimicrobial activity of crude extracts of Carica papaya (leaf and seed) against six pathogenic bacterial strains (B. subtilis, E. coli, K. pneumonia, S. aureus, $P$. aeruginosa and S. boydii).

\section{MATERIALS AND METHODS}

\section{Description of the study area}

Boricha district is found in Sidama Zone, SNNPR in Ethiopia. It is located between $6^{\circ} 46^{\prime}$ and $7^{\circ} 04^{\prime} \mathrm{N}$ latitude and $38^{\circ} 04^{\prime}$ and $38^{\circ} 24^{\prime} \mathrm{E}$ longitude. The district has an estimated area of $588.05 \mathrm{~km}^{2}$. Boricha district comprises of 42 kebeles (villages) of which 39 are rural and three are suburban towns. The district is known to be malarious as altitude falls below $2000 \mathrm{~m}$ above sea level. Boricha has an estimated total population of 236,341 of which 118,566 are men and 117,775are women. Close to $96.0 \%$ of the population is estimated to be rural inhabitants while about $4.0 \%$ are urban dwellers. The majority of inhabitants in Boricha District belong to the Sidama ethnic group whose language (Sidamu Afoo) belongs to the Cushitic language family. Land use in the district is dominated by rain-fed agriculture with small holding farms where cropping and dairy farming are commonly practiced. Maize (Zea mays), enset (Ensete ventricosum), coffee (Coffea arabica), Khat (Catha edulis), potato, sugarcane, and sweet potato are the major products and are used for consumption and as a source of income. Although the vegetation in Boricha District and other surrounding localities has currently dwindled, the area was known to be covered by Acacia forest as recently as one generation ago.

There are 47 elementary schools and three high schools in Boricha District, in which a total of 57,098 students (53\% males and $47 \%$ males) are attending their education. The district possesses six governmental health centers, one nongovernmental clinic, and thirty-nine health posts. In Boricha, the 10 leading diseases are malaria, intestinal parasites, diarrhea, upper respiratory tract diseases, urinary tract infection, rheumatism, skin diseases, and fever of unknown diseases, eye diseases, and anemia. In Boricha district besides modern medicine, traditional healers use different herbal medicines to cure these diseases. However efficacy, dosage and side effects of these herbal medicines are not well known.

\section{Study design}

For this laboratory based study, Papaya (Carica papaya) was selected. Two parts of Papaya (leaves and seeds) were obtained from Boricha woreda of Sidama zone and extracted using four extraction solvents (ethanol, acetone, methanol and water). Six microorganisms were used for the antimicrobial assays. Antimicrobial assays were carried out for each extract in triplicate and results were compared against the standard drug.

\section{Collection of plant material}

Approximately one kg of fresh leaves and seeds of Carica papaya were collected from the study area. Leaves of Carica papaya was put in polyethylene bag followed by sprinkling with water and piercing the bag at several points in order to allow air circulation. The seed samples of the test plant were placed in separate bags and transported to the laboratory in Hawassa University Main Campus. The leaf and seed samples were thoroughly washed three times by clean water followed by rinsing once with sterile distilled water. They were then placed on clean plastic plates and air dried at room temperature until their weight became constant. Then the dried samples were grounded to fine powder using electric grinder (FM100 model, China) and stored in sterile bottle at $4^{\circ} \mathrm{c}$ for analysis.

\section{Preparation of plant extracts}

The extraction methods involved solvent extraction technology. The extracts of leaf and seed of Carica papaya were prepared by dissolving $20 \mathrm{gm}$ of each fine plant powder separately in $200 \mathrm{ml}$ of $80 \%$ of acetone, $(80 \%)$ methanol, $(80 \%)$ ethanol and water. The extracts were prepared in $250 \mathrm{ml}$ capacity conical flask by soaking $20 \mathrm{~g}$ of each plant powder separately in $200 \mathrm{ml}$ of each solvent; methanol, ethanol, acetone and water for 72 hours until the soluble material became dissolved. Thereafter, each extract was filtered using Whatman no.1 filter paper and the filtrate were dried by Rota vapor until the solvent from extracts further evaporated, The resulting extracts were packed into a vial and stored at $20^{\circ} \mathrm{C}$ until further investigation.

\section{Determination of extraction yield}

The yield is the amount of extract obtained from the plant powder. It is expressed as a percentage or without any unit. In practice, it is determined by the ratio of weight of the solids content after evaporation by the weight of the dry powder of the plant material used for the extraction, multiplied by 100 .

The percentage yield of each extract was obtained using the formula:

Percent Extracts $=\frac{\mathrm{W}_{2}-\mathrm{W}_{1}}{\mathrm{~W}_{0}} \times 100$

Where, $\mathrm{W}_{2}$ is the weight of the dried Carica papaya leaf and seed extract and the container, $\mathrm{W}_{1}$ the weight of the container alone and $\mathrm{W}_{0}$ the weight of the dried Carica papaya leaf and seed.

\section{Test microorganisms}

The test Microorganisms were Gram-positive bacteria ( $S$. aureus) and Gram-negative bacteria (E. coli, K. pneumonia, B. subtilus, $P$. auruginosa and $S$. boydii). All the test microorganisms were reference strains and collected from the Microbiology Laboratory of Ethiopian public health institute (EPHI), Addis Ababa. The test organisms were grown on nutrient agar at $4^{\circ} \mathrm{C}$ and maintained in Muller Hinton agar medium according to. ${ }^{13}$

\section{Preparation of media}

The medium was prepared according to manufacturer's instructions. $38 \mathrm{~g}$ Mueller Hinton Agar was added to a flask containing $1000 \mathrm{ml}$ of distilled water and gently heated until the medium is completely dissolved. The medium was sterilized by autoclaving at $121^{\circ}$ Cor $15 \mathrm{~min}$. After cooling to about $45-50^{\circ} \mathrm{C}$, approximately $25 \mathrm{ml}$ of the sterilized medium was aseptically poured into $90 \mathrm{~mm}$ diameter sterilized Petri-dishes and allowed to dry until excess moisture from the surface of the agar is removed before use. The sterility of the prepared media was checked by incubation of randomly selected plates at $37^{\circ} \mathrm{C}$ for 24 hours. 


\section{Inoculum preparation}

This method assesses the antimicrobial activity of a bioactive compound by culturing bacteria in the presence of the compound/ extract and measuring the zone of inhibition which corresponds to the area where no bacterial growth is observed under optimum conditions for bacterial growth. The higher the diameter (zone of inhibition) the more susceptible bacteria to the bioactive compounds/extracts of plant. The method was executed according to the procedures described by ${ }^{13}$. Accordingly, three to five colonies from pure cultures of each of the six selected bacterial species were transferred with the help of a sterile wire loop into a separately labeled test tube containing $5 \mathrm{ml}$ of nutrient broth and incubated to grow at a temperature of $37^{\circ}$ for two hours. The prepared culture was standardized to $0.5 \mathrm{McF}$ arland turbidity standards using the spectrophotometer (optical density of 1.0 at 625 $\mathrm{nm}$ )by adding sterile nutrient broth to obtain the desired cell density of $1.5 \times 10^{8}$ (cells $\left./ \mathrm{ml}\right)$.

\section{Preparation of disc}

Diffusion discs of $6 \mathrm{~mm}$ diameter were prepared from absorbent filter paper (Whatman no.1) by using a paper Puncher and sterilized at $120^{\circ} \mathrm{c}$ for 1 hour and dried in oven. Then after, sterilized discs were soaked aseptically by applying $30 \mu \mathrm{l}$ of each crude extract of plant at a concentration of $100 \mathrm{mg} / \mathrm{ml}$ using sterile digital micropipette and then allowed to dry at a room temperature for 15 minutes then, placed in sterile container and stored at $4^{\circ} \mathrm{c}$ until further use.

\section{Disc diffusion test}

The disc diffusion technique has been widely used to assay plant extract for antimicrobial activity. ${ }^{14}$ A sterile cotton swabs were dipped into the adjusted standardized broth inoculums suspension by rotating the swab. The swab then evenly streaked over the entire surface of Muller Hinton agar plate. Streaking was repeated by rotating the plate approximately $60^{\circ}$ each time to ensure an even distribution of inoculum. After inoculation, for each test bacterium, a sterilized discs which were soaked under $30 \mu \mathrm{l}$ of each crude extract of plant at a concentration of $100 \mathrm{mg} / \mathrm{ml}$ were applied while sterile, blank paper discs were soaked by each solvents ethanol, methanol, acetone and water served as negative control and standard antibiotic ciprofloxacin disc $30 \mu \mathrm{g} / \mathrm{disc}$ was used as positive control.

Finally, the disc was applied on the inoculated $90 \mathrm{~mm}$ plates using flame sterilized forceps approximately equidistance to each other. Finally, all the plates were incubated at $37^{\circ}$ for 24 hours. The antibacterial activities of the plant extracts were evaluated by measuring the diameter of the inhibition zone in each of the plates at the end of the incubation period. The diameter of the inhibition zone, including the diameter of the disc was measured by using sliding digital micro caliper. The bacterial activity of the crude extracts on the test bacteria were compared with those of the negative and positive controls according to. ${ }^{13}$

\section{Minimum inhibition concentration (MIC)}

The minimum inhibitory concentration is defined as the lowest concentration which is able to inhibit any visible bacterial growth on the culture plates. ${ }^{15}$ In this study Broth macro dilution assay were used. For each plant extract a stock solution of $200 \mathrm{mg} / \mathrm{ml}$ was prepared. A $10 \mathrm{ml}$ of Muller Hinton broth was added into each sterilized test tubes. From a stock solution applying a double dilution method to bring $100 \mathrm{mg} / \mathrm{ml}, 50 \mathrm{mg} / \mathrm{ml}, 25 \mathrm{mg} / \mathrm{ml}, 12.5 \mathrm{mg} / \mathrm{ml}, 6.25 \mathrm{mg} / \mathrm{ml}, 3.125 \mathrm{mg} / \mathrm{ml}$ and $1.56 \mathrm{mg} / \mathrm{ml}$ ) were performed by using sterile digital micropipette. ${ }^{13}$

Finally, $20 \mu \mathrm{l}$ standard suspension of the test organism (which is adjusted to $0.5 \mathrm{McF}$ arland standards) was added to each tube. Mixed by gently shaking the tubes and incubated the tubes at $37^{\circ}$ for 24 hours. After 24 hours incubation, the solution was further inoculated in agar plates.
MIC was taken as the highest dilution of the extract that inhibited the growth of the bacteria. The lowest concentrations of the extracts, which inhibited the bacterial growth after a period of 24 hours of incubation at $37^{\circ}$, were recorded as MIC. Broth inoculated with test organism without extract solution was used as a positive control and only broth was used as a negative control. All testes were done in triplicates as of. ${ }^{13}$

\section{Data analysis}

For each assay, all the measurements were triplicate and the results were presented as mean $\pm \mathrm{SE}$. The statistical analyses were performed by one way ANOVA. Then Duncan`s multiple range test were used to compare means of antibacterial activity as compared to extraction solvents, plant parts and the difference in the sensitivity of the test microorganisms using the statistical package for social Sciences (SPSS) version 22 and P-values $\leq 0.05$ were considered as statistically significant.

\section{RESULT AND DISCUSSION}

\section{Percent extract yield}

In this study the highest amount of extract yield $72.5 \%$ were obtained from $80 \%$ methanol, ethanol and acetone extracts of Carica papaya leaf, while the lowest amount of extract yield 59\% was obtained from water extract of Carica papaya leaf (Table 1).

The highest amount of extract yield was observed from Carica papaya seed from water (49.5\%) followed by $80 \%$ methanol (41.5\%) and $80 \%$ ethanol (26.5\%) of Carica papaya seed. However, this result showed better extract yield than that of reported by ${ }^{16}$ on $80 \%$ ethanol $(19.7 \%)$ and water (43.2\%) crude extract. The lowest extract yield observed from Carica papaya seed (24\%) from $80 \%$ acetone solvent.

Wed mixture of solvents' varying polarity used in the extraction had a significant effect on the extraction capacity. Selecting appropriate extraction solvent is crucial in the extraction process. It has reported that different solvents have different extraction capacities and spectrum of solubility for phyto-constituents. ${ }^{16}$ Thus, the selective extraction of bioactive molecules from natural sources by appropriate solvents is important for obtaining compounds with high biological activities which can be used as preservative ingredients in the pharmaceutical industry ${ }^{17}$ which is supportive for the finding of this study.

\section{Antibacterial Assay}

The antibacterial assay of the crude extract of all tested plant parts are shown in Table 2. The highest zone of inhibitions were observed among all tested plant parts on the ethanol crude extract of Carica papaya leaf $(13.2 \pm 2.3 \mathrm{~mm})$ against pseudomonas auruginosa followed by acetone crude extract $(10.9 \pm 1.04 \mathrm{~mm})$ of Carica papaya leaf against Klebseilla pneumonia and methanol crude extract of Carica papaya leaf $(10.0 \pm 1.15 \mathrm{~mm})$ against Pseudomonas auruginosa, while the least zone

Table 1: Percent extract yield of Carica papaya leaf and seed extracted using different solvents.

\begin{tabular}{llll}
\hline Plant Type & Parts Use & Extraction Type & $\%$ Yield $(\mathrm{w} / \mathrm{w})$ \\
\hline Carica papaya & Leaf & Methanol & 72.5 \\
& & Ethanol & 72.5 \\
& & Acetone & 72.5 \\
Carica papaya & \multirow{2}{*}{ Seed } & Water & 59.0 \\
& & Methanol & 41.5 \\
& & Ethanol & 26.5 \\
& & Acetone & 24.0 \\
& & Water & 49.5
\end{tabular}


of inhibition was observed from Carica papaya leaf with ethanol crude extract $3.8 \pm 0.5 \mathrm{~mm}$ against E.coli shown in Table 2 .

The results of the antibacterial assay of the crude extract of Carica papaya seed within four different solvents showed zone of inhibition against all tested bacteria. The highest zone of inhibition observed was $14.3 \pm 1.2 \mathrm{~mm}$ on ethanol extract against Pseudomonas aeruginosa which was significantly different $(\mathrm{P}<0.05)$ from methanol $(10.3 \pm 0.3 \mathrm{~mm})$, acetone $(9.1 \pm 0.2)$ and water $(5.1 \pm 0.3)$ crude extracts against Pseudomonas aeruginosa. The highest zone of inhibition observed was $10.6 \pm 2.6 \mathrm{~mm}$ on methanol crude extract of Carica papaya seed against S.aureus, which was significantly different $(\mathrm{P}<0.05)$ from acetone crude extract $(7.4 \pm 1.4 \mathrm{~mm})$ and Water crude extract $(5.8 \pm 0.6)$. The highest zone of inhibition $(14.3 \pm 1.2 \mathrm{~mm})$ showed by Psedomonas aeruginosa with ethanol crude extract of Carica papaya, also S.aurous showed highest zone of inhibition $(10.6 \pm 2.6 \mathrm{~mm})$ with methanol crude extract. This study demonstrated a comparable result obtained from ${ }^{17}$ inhibition zone of the methanol crude extract of Carica papaya seed showed $(12 \mathrm{~mm})$ against E.coli, followed by $(9 \mathrm{~mm})$ against S.aureus, $(10 \mathrm{~mm})$ against S.typhimurium and $(8.6 \mathrm{~mm})$ against P.aerugenosa.

According to ${ }^{18}$ the ethanol extract of leaf of Carica papaya scored highest antibacterial activity $(12 \mathrm{~mm})$ against $P$.aeruginos $a$ and $(9.1 \mathrm{~mm})$ against K.pneumonia which was in agreement with the result obtained in this study. Ethanol crude extract of Carica papaya leaf showed the highest zone of inhibition $13.2 \pm 2.3(\mathrm{~mm})$ against P.aeruginosa and $12.6 \pm 1.5(\mathrm{~mm})$ against K.pneumonia which was better antibacterial activity than acetone crude extract $(10.9 \mathrm{~mm})$ against K.pneumonia and $(10.0 \mathrm{~mm})$ against P.aeruginosa. The least zone of inhibition regarding
Carica papaya leaf was observed $(3.8 \mathrm{~mm})$ with ethanol extract against E.col. The ethanol extract of Carica papaya seed shows the highest zone of inhibition $14.3 \pm 1.2(\mathrm{~mm})$ against P.aeruginosa which exhibited comparable activity to that of the standard antibiotic Ciprofloxacin (25.9 $\pm 0.0 \mathrm{~mm})$, which was significantly different $(\mathrm{P}<0.05)$ with methanol $(10.3 \pm 0.2 \mathrm{~mm})$, acetone $(9.1 \pm 0.2 \mathrm{~mm})$ and water $(5.1 \pm 0.3 \mathrm{~mm})$ crude extract of Carica papaya seed against S.aureus. Also ethanol extract of Carica papaya seed showed highest zone of inhibition against $B$. subtilis $(13.9 \pm 1.1 \mathrm{~mm})$ which was significantly different $(\mathrm{P}<0.05)$ with methanol $(7.3 \pm 1.1 \mathrm{~mm})$, acetone $(7.10 \pm 0.7 \mathrm{~mm})$ and water $(5.7 \pm 0.4 \mathrm{~mm})$ crude extract of Carica papaya seed against B. subtilis.

In the current study there was a significant difference $(\mathrm{p}<0.05)$ in antibacterial activities among the crude extracts of the two plant parts of Carica papaya (leaf and seed) depend on the extraction solvents against all tested bacteria. Comparing the mean inhibition zone of Carica papaya leaf, the crude extracts from leaf with ethanol as a solvent showed the highest inhibition zone $(9.9 \mathrm{~mm})$ against all tested bacteria and significantly different $(\mathrm{P}<0.05)$ from the three solvents. The crude extract from the leaf of Carica papaya showed mean inhibition zone with acetone extract $(8.4 \mathrm{~mm})$ and $(7.10 \mathrm{~mm})$ with methanol extract had a better antibacterial activity and also had a significant difference $(\mathrm{P}<0.05)$ among them. The lowest antibacterial activity $(6.3 \mathrm{~mm})$ showed from the crude extract of Carica papaya leaf with water as solvent. This indicated that the release of bioactive compounds on plant part depend on extraction solvent against all tested bacteria and comparing among Carica papaya leaf with different solvents, the ethanol extract of Carica papaya leaf was effective to treat those tested bacteria (Table 3).

Table 2: (Mean \pm SE) of antibacterial activities of leaf and Seed of Carica papaya crude extracts obtained using different solvents against six bacterial species.

\begin{tabular}{|c|c|c|c|c|c|c|c|}
\hline \multirow[t]{2}{*}{ Plant parts } & \multirow[b]{2}{*}{ Solvents } & \multirow[b]{2}{*}{ B.subtilis } & \multirow[b]{2}{*}{ E.coli } & \multirow[b]{2}{*}{ K.pneumonia } & \multicolumn{2}{|c|}{ Zone of inhibition } & \multirow[b]{2}{*}{ S.boydii } \\
\hline & & & & & S.aureus & P.aeruginosa & \\
\hline \multirow[t]{4}{*}{ Carica papaya leaf } & Ethanol & $7.5 \pm 0.9^{b}$ & $3.8 \pm 0.5^{b}$ & $12.6 \pm 1.5^{\mathrm{b}}$ & $12.0 \pm 0.35^{\mathrm{b}}$ & $13.2 \pm 2.3^{\mathrm{b}}$ & $10.6 \pm 2.8^{\mathrm{b}}$ \\
\hline & Methanol & $8.2 \pm 1.03^{\mathrm{b}}$ & $4.5 \pm 0.6^{\mathrm{a}}$ & $7.4 \pm 1.4^{\mathrm{a}}$ & $8.3 \pm 1.8^{\mathrm{a}}$ & $10.0 \pm 1.15^{\mathrm{a}}$ & $9.4 \pm 0.6^{\mathrm{a}}$ \\
\hline & Acetone & $7.2 \pm 0.3^{\mathrm{b}}$ & $4.5 \pm 0.3^{\mathrm{a}}$ & $10.9 \pm 1.04^{\mathrm{b}}$ & $8.1 \pm 1.4^{\mathrm{a}}$ & $10.0 \pm 0.7^{\mathrm{a}}$ & $9.7 \pm 0.5^{\mathrm{a}}$ \\
\hline & Water & $5.5 \pm 0.2^{c}$ & $7.2 \pm 1.02^{c}$ & $5.5 \pm 0.4^{\mathrm{a}}$ & $6.5 \pm 0.5^{c}$ & $6.6 \pm 0.0^{c}$ & $6.3 \pm 0.6^{c}$ \\
\hline \multirow[t]{4}{*}{ Carica papaya seed } & Ethanol & $13.9 \pm 1.1^{\mathrm{a}}$ & $13.3 \pm 1.9^{c}$ & $13.4 \pm 0.9^{\mathrm{b}}$ & $12.5 \pm 0.1^{\mathrm{c}}$ & $14.3 \pm 1.2^{\mathrm{b}}$ & $12.5 \pm 1.03^{b}$ \\
\hline & Methanol & $7.3 \pm 1.1^{\mathrm{a}}$ & $10.3 \pm 0.6^{\mathrm{b}}$ & $8.10 \pm 1.6^{\mathrm{a}}$ & $10.6 \pm 2.6^{\mathrm{b}}$ & $10.3 \pm 0.2^{\mathrm{a}}$ & $8.7 \pm 0.3$ \\
\hline & Acetone & $7.10 \pm 0.7^{\mathrm{a}}$ & $7.9 \pm 1.3^{\mathrm{a}}$ & $9.5 \pm 0.5^{\mathrm{a}}$ & $7.4 \pm 1.4^{\mathrm{a}}$ & $9.1 \pm 0.2^{\mathrm{a}}$ & $8.0 \pm 0.5^{\mathrm{a}}$ \\
\hline & Water & $5.7 \pm 0.4^{c}$ & $6.9 \pm 0.3^{\mathrm{a}}$ & $5.5 \pm 0.2^{c}$ & $5.8 \pm 0.6^{\mathrm{a}}$ & $5.1 \pm 0.3^{c}$ & $7.6 \pm 0.5^{\mathrm{a}}$ \\
\hline +ve control & & $23.9 \pm 0.0$ & $25.3 \pm 0.0$ & $21.1 \pm 0.0$ & $25.2 \pm 0.0$ & $25.9 \pm 0.0$ & $24.4 \pm 0.0$ \\
\hline -ve control & & $0.0 \pm 0.0$ & $0.0 \pm 0.0$ & $0.6 \pm 0.6$ & $0.0 \pm 0.0$ & $0.0 \pm 0.0$ & $0.0 \pm 0.0$ \\
\hline
\end{tabular}

Table 3: Plant parts by extraction solvent interaction effect on antibacterial activity of Carica papaya plant.

\begin{tabular}{|c|c|c|c|c|c|}
\hline \multirow[b]{2}{*}{ Plant parts } & \multirow[b]{2}{*}{ Solvents } & \multicolumn{3}{|c|}{$95 \%$ confidence interval for mean } & \multirow[b]{2}{*}{ Upper bound } \\
\hline & & Mean & Standard Deviation & Lower bound & \\
\hline \multirow[t]{4}{*}{ Carica papaya leaf } & Ethanol & $9.9^{\mathrm{b}}$ & 4.2 & 7.8 & 12.0 \\
\hline & Methanol & $7.10^{\mathrm{a}}$ & 2.5 & 6.7 & 9.2 \\
\hline & Acetone & $8.4^{c}$ & 2.5 & 7.2 & 9.6 \\
\hline & Water & $6.3^{\mathrm{d}}$ & 1.0 & 5.8 & 6.8 \\
\hline \multirow[t]{4}{*}{ Caricapapaya seed } & Ethanol & $13.3^{\mathrm{d}}$ & 1.8 & 12.4 & 14.2 \\
\hline & Methanol & $9.4^{\mathrm{b}}$ & 2.3 & 8.2 & 10.5 \\
\hline & Acetone & $8.3^{\mathrm{a}}$ & 1.5 & 7.6 & 9.1 \\
\hline & Water & $6.1^{\mathrm{c}}$ & 1.1 & 5.6 & 6.4 \\
\hline
\end{tabular}

Mean values under the same category that bear different superscript letters are significantly different $(p<0.05)$

Table 4: Plant parts of Carica papaya leaf and seed interaction with bacterial spp.

\begin{tabular}{lccc} 
Plant parts & Mean & \multicolumn{2}{c}{ 95\% Confidence Interval for Mean } \\
\cline { 3 - 4 } & & Standard Error & Upper bound \\
Carica papaya leaf & $13.2^{\mathrm{a}}$ & 2.3 & 3.4 \\
Carica papaya seed & $14.3^{\mathrm{b}}$ & 1.2 & 22.9 \\
\end{tabular}


Table 5: Minimum inhibitory concentrations $(\mathrm{mg} / \mathrm{ml})$ of Carica papaya leaf and seed with four different extraction solvents.

\begin{tabular}{|c|c|c|c|c|c|c|c|}
\hline \multirow[t]{2}{*}{ Plant parts } & \multirow[t]{2}{*}{ Extraction solvent } & \multicolumn{6}{|c|}{ Bacterial species } \\
\hline & & B.subtilis & E.coli & K.pneumonia & S.aureus & P.aeruginosa & S.boydii \\
\hline \multirow[t]{4}{*}{ Carica papaya leaf } & Ethanol & 50 & 50 & 12.5 & 12.5 & 12.5 & 50 \\
\hline & Methanol & 12.5 & 12.5 & 25 & 50 & 50 & 25 \\
\hline & Acetone & 50 & 50 & 50 & 50 & 50 & 50 \\
\hline & Water & 100 & 100 & 100 & 100 & 100 & 100 \\
\hline \multirow[t]{4}{*}{ Carica papaya seed } & Ethanol & 25 & 25 & 25 & 25 & 12.5 & 100 \\
\hline & Methanol & 50 & 50 & 100 & 100 & 100 & 100 \\
\hline & Acetone & 50 & 100 & 100 & 100 & 50 & 25 \\
\hline & Water & 100 & 100 & 100 & 100 & 100 & 100 \\
\hline
\end{tabular}

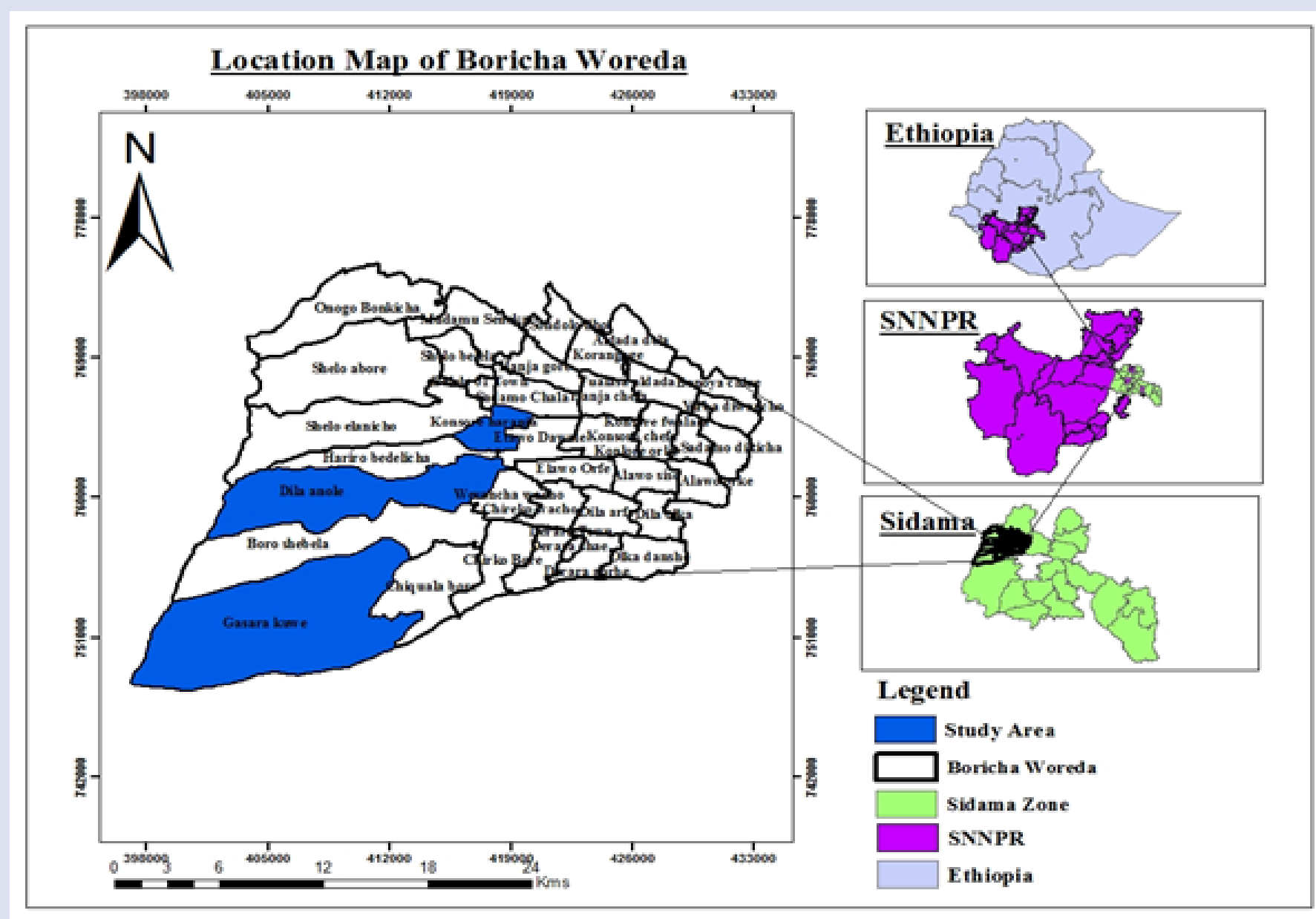

Figure 1: Map of Boricha woreda.

In the case of the seed solvent extract of Carica papaya the ethanol extract had the highest $(13.3 \mathrm{~mm})$ antibacterial activity against all tested bacteria and significantly different $(\mathrm{p}<0.05)$ from the methanol $(9.4 \mathrm{~mm})$, acetone $(8.3 \mathrm{~mm})$ and water $(6.1 \mathrm{~mm})$ crude extract of Carica papaya seed. There was no significance difference $(\mathrm{p}>0.05)$ among methanol $(9.4 \mathrm{~mm})$ and acetone $(8.3 \mathrm{~mm})$ crude extract of Carica papaya seed but significantly different $(\mathrm{p}<0.05)$ from water $(6.1 \mathrm{~mm})$ and ethanol $(13.3 \mathrm{~mm})$ crude extract in their zone of inhibition against all tested bacteria. The least zone of inhibition $(6.1 \mathrm{~mm})$ was observed from water crude extract of Carica papaya seed against all tested bacteria. Comparing among Carica papaya seed with different solvents, the ethanol extract of Carica papaya seed was effective to treat those tested bacteria (Table 3).

Among all tested plant parts (Carica papaya leaf and Carica papaya seed), Carica papaya seed had a better antibacterial activity $(14.3 \mathrm{~mm})$ and significantly different $(\mathrm{p}<0.05)$ from Carica papaya leaf $(13.2 \mathrm{~mm})$ against all tested bacteria. This result indicated that Carica papaya seed had high antibacterial activity than the Carica papaya leaf against all tested bacteria (Table 4).

\section{Minimum inhibitory concentration (MIC)}

The MIC assay was also employed to evaluate the effectiveness of the extracts to inhibit the growth of the tested bacteria. The ethanol crude extract of Carica papaya leaf has inhibited B.subtilis, E.coli and S.boydii at a concentration of $50 \mathrm{mg} / \mathrm{ml}$ and at $12.5 \mathrm{mg} / \mathrm{ml}$ has been inhibited K.pneumonia, S.aureus and P.aeruginosa. Methanol extract inhibited B.subtilis and E.coli at a concentration of $12.5 \mathrm{mg} / \mathrm{ml} ; K$. pneumonia and S. boydii at a concentration of $25 \mathrm{mg} / \mathrm{ml}$ and S.aureus and P.aeruginosa at a concentration of $50 \mathrm{mg} / \mathrm{ml}$ inhibited. Among acetone crude extracts of Carica papaya leaf the MIC was $50 \mathrm{mg} / \mathrm{ml}$ which inhibited all tested 
bacterial species. The water crude extracts of all tested plant parts were at $100 \mathrm{mg} / \mathrm{ml}$ which inhibited all tested bacterial species. The MIC value of methanol extract of Carica papaya leaf against E. coli was $12.5 \mathrm{mg} / \mathrm{ml}$ which was agreed with the result of. ${ }^{19}$

Among ethanol crude extract of Carica papaya seed the MIC was $12.5 \mathrm{mg} / \mathrm{ml}$ for $P$. aeruginosa, $25 \mathrm{mg} / \mathrm{ml}$ for B. subtilis, E. coli, $K$ .pneumonia and S. aureus. At the MIC was $100 \mathrm{mg} / \mathrm{ml}$ for S. boydii. In the case of methanol crude extracts of Carica papaya seed $50 \mathrm{mg} / \mathrm{ml}$ for B. subtilis and E.coli; $100 \mathrm{mg} / \mathrm{ml}$ for K. pneumonia, P. aeruginosa, $S$. aureus and $S$. boydii. The acetone crude extract MIC of Carica papaya seed was $50 \mathrm{mg} / \mathrm{ml}$ that inhibited B. subtilis and P. aeruginosa. Also $25 \mathrm{mg} / \mathrm{ml}$ inhibited S. boydii and $100 \mathrm{mg} / \mathrm{ml}$ inhibited E. coli, $K$. pneumonia and $S$. aureus. The water crude extracts of all tested plant parts were at $100 \mathrm{mg} / \mathrm{ml}$ which inhibited all tested bacterial species.

The tested plant parts which were extracted with different solvents showed different MIC. The methanol crude extract of Carica papaya leaf had a potential to inhibit B. subtilis and E. coli at $12.5 \mathrm{mg} / \mathrm{ml}$. So, it had a potential to treat $B$. subtilis and E. coli. Also the ethanol crude extract of Carica papaya seed had a potential to inhibit $P$. aeruginosa at $12.5 \mathrm{mg} / \mathrm{ml}$. So, it had a potential for treating of $P$. aeruginosa.

\section{CONCLUSION}

The results of the antibacterial assay of the crude extract of Carica papaya (leaf and seed) with four different solvents showed zone of inhibition against all tested bacteria. However, among the plant parts of Carica papaya included in the current study, the seed of Carica papaya were found to be the best source of antibacterial agents. Likewise, among the extraction solvents employed for the current study, $80 \%$ ethanol, methanol and acetone were found to be the best extraction solvents. The MIC assay was also employed to evaluate the effectiveness of the extracts to inhibit the growth of the tested bacteria. Among ethanol crude extract of Carica papaya seed at $12.5 \mathrm{mg} / \mathrm{ml}$ inhibited P.aeruginosa. At $25 \mathrm{mg} / \mathrm{ml}$ inhibited B.subtilis, E.coli, K.pneumonia and S.aureus and at $100 \mathrm{mg} / \mathrm{ml}$ inhibited S. boydii. Carica papaya seed with methanol crude extract exhibited high antibacterial activity against S. aureus at $100 \mathrm{mg} / \mathrm{ml}$ this extract showed comparable antimicrobial activity with positive control Ciprofloxacin disc $30 \mu \mathrm{g}$ against $S$. aureus while, no growth inhibition was observed in the case of all the negative controls. This shows the potential of the plant for developing drugs for treating various illnesses in human beings. The susceptibility of the six bacteria species appeared to be influenced by the plant part and the extraction solvent used. MIC ranged from $3.125 \mathrm{mg} / \mathrm{ml}$ to $200 \mathrm{mg} / \mathrm{ml}$ with absolute water. This result confirmed that extract of medicinal plant showed a comparable result to standard antibiotics.

\section{REFERENCES}

1. Duarte MC, Figueira GM, Sartoratto A, Rehder VL, Delarmelina C. Anti-Candida activity of Brazilian medicinal plants. J Ethnopharmacol 2005; 97:305-11.

2. Renisheya JJ, Malar T, Johnson M, Mary UM, Arthy A. Antibacterial activities of ethanolic extracts of selected medicinal plants against human pathogens. Asian Pac J Trop Biomed 2011; 576-578.
3. Bushra I, Fozia Abdul W, Ali R, Ullah Hussain, Iqbal Hamid, Almas M, Ahmad A. Antimicrobial activity of Malvaneglecta and Nasturtium microphyllum. Int J Res Ayurveda Pharm 2012; 3: 808-810.

4. Bibi, Y., Nisa, S., Chaudhary, F. and Zia, M. (2011). Antibacterial activity of some selected medicinal plants of Pakistan. BMC ComplemAltern Med. 11: 892-897.

5. Munir S, Jamal Q, Shirwani S, Sualeh M, Jabeen U, Malik MS, Hussain M. Antibacterial activity of two medicinal plants, with aniasomnifera and Cuccuma longa. EurAcad Res, 2013; 1: 1335-1345.

6. Satyal P, Paudel P, Kafle A, Pokharel SK, Lamichhane B, Dosoky NS Moriarity DM, Setzer WN. Bioactivities of volatile components from Nepalese Artemisia species. Nat Prod Commun 2012; 12: 1651-8122.

7. Liu WJH, John Sons W. Introduction to Traditional Herbal Medicines and their Study, in Traditional Herbal Medicine Research Methods: Identification, Analysis, Bioassay, and Pharmaceutical and Clinical Studies 2011.

8. Gidey M. An ethnobotanical study of medicinal plants used by the zay people in Ethiopia. Skriftserie 2001; 3:81-99.

9. Demissew S, Dagne E. Basic and applied research on medicinal plants of Ethiopia. In: Proceedings of the National Workshop on Conservation and Sustainable Use of Medicinal Plants in Ethiopia, Addis Ababa 2000; P. 29.

10. Fhogartaigh CN, Edgeworth JD. Bacterial gastroenteritis. Medicine 2009; 37(11):586-593

11. Nascimento GGF, Locatelli JPC, Freitas PC, Silva GL. Antibacterial activity of plant extracts and phytochemicals on antibiotic resistant bacteria. Braz. J. Microbiol 2000; 31: 24756.

12. Vermani K, Garg S. Herbal medicine for sexually transmitted diseases and AIDS. Journal of Ethnopharmacology 2002; 80: 49-66.

13. CLSI (Clinical and Laboratory Standards Institute). Methods for dilution antimicrobial susceptibility tests for bacteria that grow aerobically approved standard. 9thed. Wayne. 2012; 32.

14. Taiwo SS, Oyekanmi BA, Adesiji YO, Opaleye OO, Adeyeba OA. In vitro antimicrobial activity of crude extract of Citrus aurantifolia Linn and Titonia diversifolia (Poaceae) on clinical bacterial isolates. International Journal of Tropical Medicine 2007; 2 (4):113 - 117.

15. Radojevic, I., Stankovic, O., Topuzovic, M., Comic, L. and Ostojic, A. (2012). Great Horsetail (Equisetum telmateia Ehrh.): Active Substances Content and Biological Effects. Experimental and Clinical Sciences International Journal, 11:59-67, 5:237-243.

16. Arvind Kumar Sharma, Amit Kumar, Sharad Kumar Yadav, Anu Rahal. Studies on Antimicrobial and Immunomodulatory Effects of Hot Aqueous Extract of Acacia nilotica L. Leaves against Common Veterinary Pathogens. Veterinary Medicine International, 2014: 1-9.

17. Calzada F, Yepez-Mulia L, Tapia-Contreras A. Effect of Mexican Medicinal Plants used to treat trichomoniasis on Trichomonas vaginalis trophozoites. Journal of Ethnopharmacol 2007; 113(2):248-251.

18. Osato JA, Santiago LA, Remo GM, Cuadra MS, Mori A. Antimicrobial and antioxidant activities of unripe Papaya. Life Science 1993; 53(17): 1383-1389.

19. Eno K, Regli T, Bilsel G. Evaluation of antimicrobial activity of plant extracts on antibiotic susceptible and resistant Staphylococcus aureus strains. J. Chem. Pharm. Res, 2000; 3(4):769-781. 


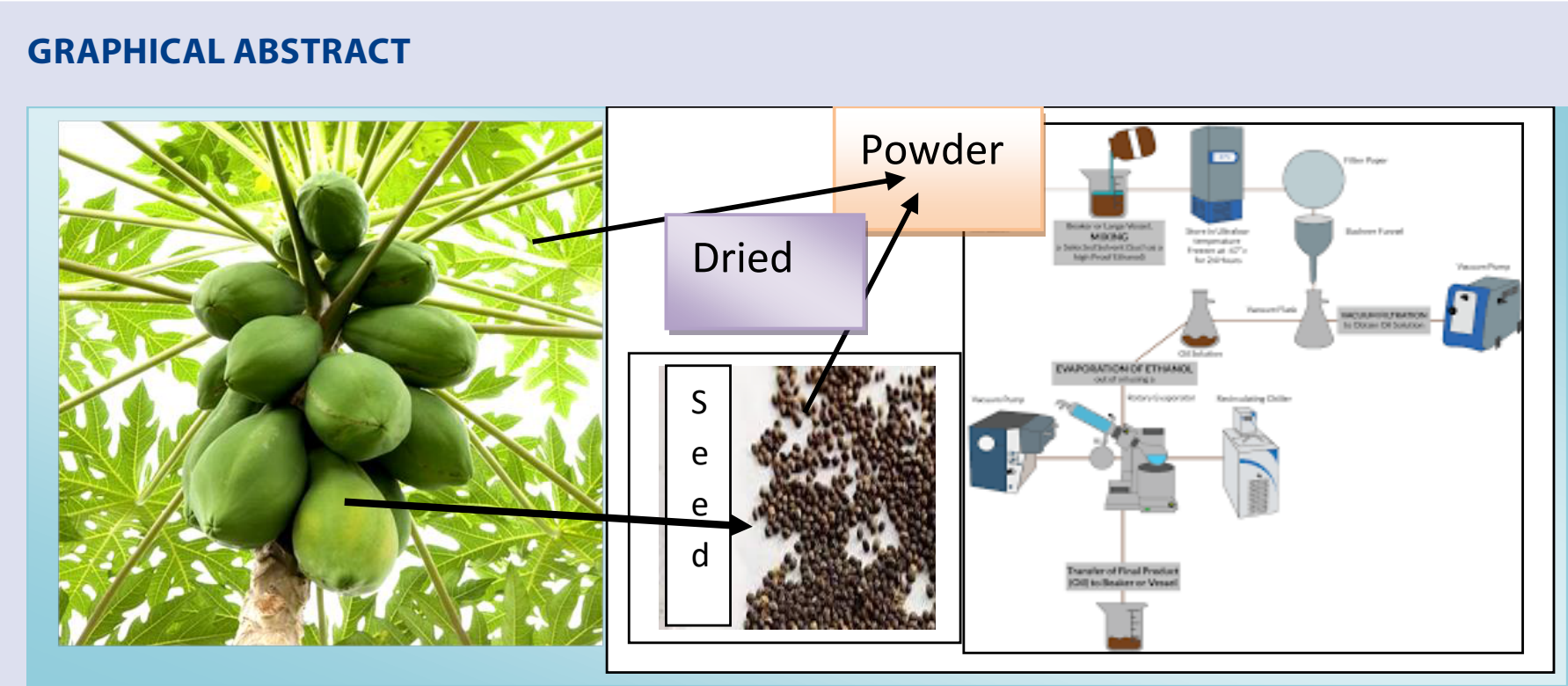

\section{ABOUT AUTHORS}

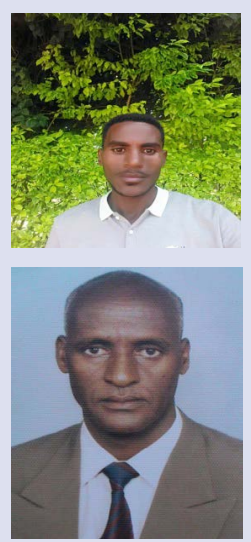

\section{Eshetu Dagne}

MSc student of Applied Microbiology College of Natural and Computational Science, Faculty of Biological Science, Department of Biology, Hawassa University, Ethiopia.

\section{Beyene Dobo}

Associate professor of Microbiology College of Natural and Computational Science, Faculty of Biological Science, Department of Biology, Hawassa University, Ethiopia.

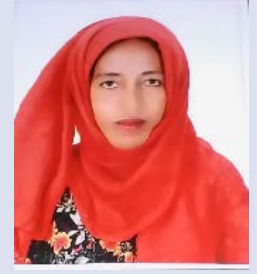

\section{Zufan Bedewi}

Assistant professor of Biomedical Sciences, Head, faculty of Biological Science, College of Natural and Computational Science, Department of Biology, Hawassa University, Ethiopia.

Cite this article: Dagne E, Dobo B, Bedewi Z. Antibacterial Activity of Papaya (Carica papaya) Leaf and Seed Extracts Against Some Selected Gram-Positive and Gram-Negative Bacteria. Pharmacogn J. 2021;13(6)Suppl: 1727-1733. 